\title{
Clinical and subclinical mastitis in buffalue in Mosul area, Iraq
}

\author{
A.S. Saadoon \\ Department of Animal Production, College of Agriculture and Forestry, University of Mosul, Mosul, Iraq
}

\begin{tabular}{l} 
Article information \\
\hline Article history: \\
Received March 01, 2021 \\
Accepted June 12, 2021 \\
Available online December 12, 2021 \\
\hline Keywords: \\
Clinical mastitis \\
Subclinical mastitis \\
Buffaloes \\
Mosul \\
\\
\hline Correspondence: \\
A.S. Saadoon \\
abdstar@uomosul.edu.iq
\end{tabular}

\begin{abstract}
This paper aims to investigate the occurrence of clinical and sub-clinical cases of mastitis in buffaloes, and to identify the differences in the components of the mastitis milk, to facilitate the investigation of a number of epidemiological risk aspects in relation to the occurrence of mastitis and to detect the different bacterial species associated with the disease. Eight hundred buffalo milk samples were randomly extracted from the animals of different ages in Mosul city, Iraq and examined by California mastitis test (CMT) and Ultrasonic milk analyzer. According to the clinical signs and CMT, the results indicated the prevalence of the clinical and subclinical cases of the disease in buffaloes to be $10.62 \%$ and $27.37 \%$ respectively. There was a substantial rise in the population of somatic cells $/ \mathrm{ml}$ in both clinical and subclinical cases of mastitis. The risk factors included third trimester of lactation period, old ages 10-11 years, outdoor feeding animals, $>30$ buffaloes/herd, northern and southern parts of the city, Spring and Winter seasons. In clinical instances of mastitis, the occurrence of Staphylococcus aureus was 25.88\%, Streptococcus agalactiae 18.82\%, Streptococcus pyogenes $16.47 \%$, Corynebacterium bovis $14.11 \%$, Escherichia coli $10.58 \%$, Pseudomonus aeruginosa $7.05 \%$, and Pasteurella multocida $7.05 \%$. In the subclinical cases of mastitis, the prevalence of Staphylococcus chromogens was $14.61 \%$, Staphylococcus xylosus $12.78 \%$, Streptococcus agalactiae $11.87 \%$, Streptococcus dysagalactiae $11.41 \%$, Streptococcus uberis $10.04 \%$, Proteus vulgaris $10.04 \%$, Klebsiella pneumonae $9.58 \%$, Escherichia coli $8.21 \%$, Corynebacterium bovis $7.30 \%$, and Pasteurella multocida $4.10 \%$. It is concluded that mastitis leads to a significant reduction in the levels of total solids, lactose, protein, fat, density, and a significant rise in the levels of $\mathrm{pH}$ values and electrical conductivity of the milk samples of clinical and subclinical cases of mastitis.
\end{abstract}

DOI: 10.33899 /ijvs.2021.129644.1671, (CAuthors, 2022, College of Veterinary Medicine, University of Mosul.

This is an open access article under the CC BY 4.0 license (http://creativecommons.org/licenses/by/4.0/).

\section{Introduction}

The Bubaline mastitis is explained as inflammation of the parenchyma of the mammary gland of buffaloes that can be of traumatic, infectious or toxic nature and it is characterized by physical, chemical and cytological changes in the composition of the milk and pathological alterations in the mammary glandular tissue (1). In addition, it leads to the existence of a number of infectious agents including bacteria, which could be hazardous to human beings. The clinical cases of the disease typically involve the incidence of swelling, edema, discomfort and heat in the mammary gland of most clinical cases of mastitis linked to multiple variations in the physical and chemical make-up of the milk like the existence of clots, pus, blood, water, flakes and shreds containing fibrin and cellular debris associated with pathological alterations in the mammary gland tissues (2). The clinical cases of mastitis occur due to infectious agents, and may be classified according to their severity in peracute, acute, subacute and chronic cases (3). The acute cases of mastitis initiate suddenly and are generally associated with systemic reactions such as inappetence, 
fever, decrease in milk production, dehydration, and occurrence of milk changes (4). The subacute cases of the disease are characteristically without clinical symptoms except a limited number of mild indications of milk alterations without systemic reactions (5), while in chronic cases of mastitis there is gradual fibrosis leading to increase in the size of the infected quarter and asymmetry of the quarters (6). The subclinical cases of mastitis cannot be detected by manual palpation or by visually examining the milk with the use of a strip cup, but detection is possible using laboratory testing (7). Generally, the cases of mastitis are caused by interaction between different microbial infections and host responses in the mammary gland, which is affected by the way the buffaloes are managed. The risk factors of mastitis include poor milking techniques, inappropriate husbandry, unsatisfactory ventilation, low hygiene standards, overcrowding and milking machine malfunction (6). The mastitis-causing bacteria are classified into contagious and environmental pathogens (1). Most infections are the result of the first type of pathogens, including Streptococcus agalactia, Staphylococcus aureus, Mycoplasma spp., Pseudomonus aeruginosa, Arcanobacter pyogenes, while the environmentally-related pathogens comprise Streptococcus dysgalactiae, Streptococcus uberis, Enterobacteriacae spp., Escherichia coli, moulds, yeasts and coagulase negative Staphylococci (8-12). The second type of pathogens can be found in soil, faeces, litter, and on milking equipment, which are responsible for causing teat lesions that can encourage the invasion and penetration of different types of microorganisms into the udder tissues resulting in mastitis (13). The occurrence of subclinical mastitis in buffaloes exceeds than of clinical mastitis, at $18.5 \%$ compared to $9 \%$ respectively (12).

Diagnosing the disease depends on the clinical symptoms for the clinical cases of mastitis, as well as laboratory tests for the subclinical cases of mastitis. The laboratory tests include CMT, Modified Whiteside test (MWT), and the determination of somatic cell count (SCC), which is carried out microscopically or by an automatic counter (optofluorimetic method), and determination of the electrical conductivity (EC) of the milk $(14,15)$. The healthy quarters produce milk with $<100,000$ somatic cells $/ \mathrm{ml}$ of milk and without bacterial infections, while the quarters that produce milk with $>200,000$ somatic cells $/ \mathrm{ml}$ are considered as subclinical infection (16-18). The increase of the SCC is at a gradual rate after the first 90 days of lactation and after the second or third parturitions in buffaloes $(14,19)$. The aims of this particular research were to determine the occurrence of the clinical and subclinical cases of the disease in buffaloes in Mosul city, and also to determine the SCCs in the milk samples, to find out the differences in the components of the mastitis milk, to examine a number of epidemiological risk factors that accompany the prevalence of mastitis and to affirm the different bacterial spp.

\section{Materials and methods}

\section{Animals and sample collection}

For this research, 800 samples of buffalo milk were obtained at random from buffaloes located in the eastern, northern, western, southern and central parts of Mosul city/Iraq. The ages of the buffaloes were between 4 and 12 years. A $20 \mathrm{ml}$ of milk sample was obtained from individual teats after washing and disinfecting the teats with tincture of Iodine $0.1 \%$ in sterile vials, then transported in cold boxes to the laboratory. The respiratory rate/min, heart rate/min, rumenal movements $/ 5 \mathrm{~min}$ and rectal temperature of the animals were recorded. The mammary glands of the buffaloes were examined through manual palpation to detect clinical cases of mastitis. The milk samples were physically examined and also visually inspected to detect abnormal changes in the odor, consistency, color of the samples in addition to the presence of threads, clots or precipitates according to (20). Diagnosing of the clinical cases of mastitis was done according to the cardinal manifestations of udder inflammation, including heat, swelling, redness, pain, and edema in the mammary gland, in addition to the clinical manifestations associated with mastitis, including increase in heart rate/min, respiratory rate/min, rectal temperature and rumenal movements $/ 5 \mathrm{~min}$. The number of infected animals with clinical mastitis in this study was 85 animals while the number of control group was 50 animals.

\section{California mastitis test (CMT)}

The samples of milk were mixed gently, then the CMT was conducted by adding equal quantities of CMT reagent and milk in a paddle. The reaction occurred after mixing the mixture in a gently circular motion of the paddle. Finally, the results were recorded according to (20).

\section{Examination of the milk samples with Ultrasonic milk analyzer (Eko-milk Analyzer)}

The milk samples were examined directly within two hours after collection by using Ultrasonic Milk Analyzer machine (Eon-Trading company/ Bulgaria). The machine estimated the EC of the milk samples, the percentage of total solids, lactose, protein, fat, $\mathrm{pH}$ as well as the density of the milk samples.

\section{Somatic cell count}

The milk samples were mixed thoroughly by vortexing and the cream was dispersed throughout the specimen. This was followed by the spreading of, $0.01 \mathrm{ml}$ of milk over 1 sq.cm area on a slide ( $1 * 3$ inch). The slides were dried over a flat surface without heating, then the slides were stained with Newman-Lampert stain to show the leukocytes. The microscopic examination was carried out carefully to estimate the number of somatic cells by multiplying the average of somatic cells in 30-50 fields by the microscopic 
factor by 100 . This method gave the SCC per milliliter of milk (20).

\section{Bacterial culture and identification}

The number of milk samples cultured was 304(85 samples from clinical cases and 219 samples from subclinical cases). Culturing of the milk samples was done on ordinary media, namely Blood agar, Nutrient agar, MacConkey agar (Himedia company, India) and incubated at $37^{\circ} \mathrm{C}$ for 24 hours. Following the development of bacterial colonies on these media, a slide was made from the colonies, then stained with Gram's stain. The bacterial colonies were subcultured on selective media such as Hoyles media for Corynebacterium spp, Edward's media for Streptococcus spp, Manitol salt agar and Staphylococcus medium No. 110 for Staphylococcus spp (Difco company, USA). Following that, the biochemical tests were carried out including Oxidase test, Methyl red test, Indole test, Citrate utilization test, Voges-proskauer test, Catalase test, Urate test, Nitrate reduction test, Sugar fermentation test and Coagulase test according to (21) to identify the different bacterial species. Fifty milk samples without bacterial isolates were considered as control.

\section{Statistical analysis}

Following the One-way analysis of variance (ANOVA) was the performance of the post-hoc test (Duncan) in the same program, which was utilized to compare the clinical cases, subclinical cases and control group for clinical signs, chemical analysis of milk samples and SCCs, while the differences in the prevalence of mastitis between several risk factors was appraised by utilizing two-sided Chi-square and Fischer's exact test in IBM-SPSS statistics version 19 program and the relative risk (RR) for the relationship among risk factors for mastitis by employing $2 \times 2$ tables in Epi-Info TM 7 software (version 7).

\section{Results}

According to the clinical signs it was found that $10.63 \%$ (85 out of 800) of the animals were infected with clinical mastitis, while $27.37 \%$ (219 out of 800 ) of them were infected with subclinical mastitis according to CMT (Table 1). The infected animals with the clinical cases of mastitis showed evidence of swelling of the infected quarters accompanied by pain, redness of the teat, and heat in addition to the presence of flakes, clots, purulent material or blood in the milk. All the clinical signs were present in one quarter. The results of CMT for the milk samples indicated that the degrees of reaction were $(+)$ in 93 milk samples and $(++)$ in 126 milk samples (Table 1). The results of statistical analysis of the clinical signs revealed a significant rise in the heart as well as respiratory rate/min and rectal temperature of the infected animals with clinical cases of mastitis in comparison with control, while there was a significant reduction in the rumenal movement $/ 5 \mathrm{~min}$ of the clinical mastitis infected animals in comparison with control (Table 2). In the current study, there was a considerably increased SCC in the milk samples of infected animals with subclinical and clinical cases of the disease in comparison with the control group (Table 3).

The chemical composition of the milk samples of the infected animals with subclinical and clinical cases of mastitis was statistically analyzed and revealed the presence of a significant decrease in the amount of overall solids, lactose, protein, fat, and density of the milk samples of the infected animals with subclinical and clinical forms of mastitis in comparison with their levels in the control group, while there was a significant rise in the levels of electrical conductivity (EC) and $\mathrm{pH}$ of the milk samples of the infected animals with subclinical and clinical forms of mastitis compared to their levels in the control group (Table 4).

Table 1: Results of CMT for milk samples of buffaloes infected with subclinical cases of mastitis ( $\mathrm{n}=800)$

\begin{tabular}{lccc}
\hline Type of infection & Reaction degree & No. of positive samples & Infection rate (\%) \\
\hline Subclinical infection & + & 93 & \\
Subclinical infection & ++ & 126 & 27.37 \\
\hline Total & & 219 & \\
\hline
\end{tabular}

Table 2: The clinical signs of the clinical, subclinical cases of mastitis and control group in buffaloes (mean $\pm \mathrm{SE}$ )

\begin{tabular}{lccc}
\hline Clinical symptoms & Clinical mastitis & Subclinical mastitis & Control group \\
& 85 animals & 219 animals & 50 animals \\
\hline Heart rate/min & $96.4 \pm 4.21^{\mathrm{a}}$ & $76.8 \pm 6.24^{\mathrm{b}}$ & $73.8 \pm 4.32^{\mathrm{b}}$ \\
Respiratory rate/min & $79.4 \pm 5.37^{\mathrm{a}}$ & $35.4 \pm 4.62^{\mathrm{b}}$ & $33.8 \pm 3.53^{\mathrm{b}}$ \\
Rumenal movements/5min & $1.8 \pm 0.7^{\mathrm{b}}$ & $3.2 \pm 0.3^{\mathrm{a}}$ & $4.4 \pm 0.2^{\mathrm{a}}$ \\
Rectal temperature ${ }^{\circ} \mathrm{C}$ & $41.1 \pm 0.31^{\mathrm{a}}$ & $38.7 \pm 0.24^{\mathrm{b}}$ & $38.2 \pm 0.53^{\mathrm{b}}$ \\
\hline
\end{tabular}

Mean values \pm Standard error (S.E.) significantly different $(\mathrm{P}<0.05)$ between buffaloes, and those of healthy status are labeled with different superscript letters $\left({ }^{\mathrm{a}},{ }^{\mathrm{b}}\right.$ or $\left.{ }^{\mathrm{c}}\right)$. 
Table 3: Number of somatic cells/ml of milk samples of buffaloes infected with clinical, subclinical cases of mastitis and control group (mean $\pm \mathrm{SE})$

\begin{tabular}{lccc}
\hline Age & $\begin{array}{c}\text { Milk samples of Clinical cases } \\
\text { No. of Somatic cells/ml } \\
(85 \text { samples })\end{array}$ & $\begin{array}{c}\text { Milk samples of Subclinical cases } \\
\text { No. of Somatic cells/ml (x10 } \\
(219 \text { samples })\end{array}$ & $\begin{array}{c}\text { Milk samples of Control group } \\
\text { No. of Somatic cells/ml (x10 } \\
(50 \text { samples })\end{array}$ \\
\hline 4-5 years & $1284 \pm 36.2^{\mathrm{a}}$ & $324 \pm 10.4^{\mathrm{b}}$ & $74 \pm 4.2^{\mathrm{c}}$ \\
6-7 years & $1458 \pm 29.6^{\mathrm{a}}$ & $336 \pm 12.8^{\mathrm{b}}$ & $79 \pm 6.8^{\mathrm{c}}$ \\
8-9 years & $1648 \pm 42.7^{\mathrm{a}}$ & $347 \pm 17.3^{\mathrm{b}}$ & $86 \pm 8.4^{\mathrm{c}}$ \\
10-11 years & $1795 \pm 48.3^{\mathrm{a}}$ & $385 \pm 16.8^{\mathrm{b}}$ & $92 \pm 6.7^{\mathrm{c}}$ \\
\hline
\end{tabular}

Mean values \pm Standard error(S.E.) significantly different $(\mathrm{P}<0.05)$ between buffaloes, and those of healthy status are labeled with different superscript letters.

Table 4: Results of chemical analysis of milk samples of buffaloes infected with clinical, subclinical cases of mastitis and control group (Mean \pm S.E)

\begin{tabular}{|c|c|c|c|c|}
\hline $\begin{array}{l}\text { Age } \\
\text { (year) }\end{array}$ & Milk components & $\begin{array}{l}\text { Milk samples of Clinical } \\
\text { cases (85 samples) }\end{array}$ & $\begin{array}{l}\text { Milk samples of Subclinical } \\
\text { cases ( } 219 \text { samples) }\end{array}$ & $\begin{array}{l}\text { Milk samples of Control } \\
\text { group (50 samples) }\end{array}$ \\
\hline \multirow{7}{*}{$4-5$} & Total solids \% & $13.14 \pm 1.16^{\mathrm{b}}$ & $13.23 \pm 1.21^{\mathrm{b}}$ & $16.45 \pm 1.32^{\mathrm{a}}$ \\
\hline & Lactose \% & $3.47 \pm 0.26^{b}$ & $3.52 \pm 0.41^{\mathrm{b}}$ & $4.71 \pm 0.27^{\mathrm{a}}$ \\
\hline & Protein $\%$ & $3.92 \pm 0.32^{b}$ & $3.88 \pm 0.25^{b}$ & $5.32 \pm 0.22^{\mathrm{a}}$ \\
\hline & Fat $\%$ & $5.74 \pm 0.83^{b}$ & $5.62 \pm 0.95^{b}$ & $7.88 \pm 1.24^{\mathrm{a}}$ \\
\hline & $\mathrm{pH}$ & $7.59 \pm 0.32^{\mathrm{a}}$ & $7.64 \pm 0.46^{\mathrm{a}}$ & $6.94 \pm 0.30^{b}$ \\
\hline & Density $\mathrm{gm} / \mathrm{ml}$ & $1.025 \pm 0.006^{b}$ & $1.022 \pm 0.004^{b}$ & $1.038 \pm 0.002^{\mathrm{a}}$ \\
\hline & Electrical conductivity & $8.26 \pm 0.26^{\mathrm{a}}$ & $6.14 \pm 0.014^{b}$ & $3.12 \pm 0.004^{\mathrm{c}}$ \\
\hline \multirow{7}{*}{$6-7$} & Total solids \% & $12.37 \pm 1.54^{b}$ & $12.74 \pm 1.72^{b}$ & $16.37 \pm 1.64^{\mathrm{a}}$ \\
\hline & Lactose \% & $3.35 \pm 0.31^{\mathrm{b}}$ & $3.63 \pm 0.2^{b}$ & $4.64 \pm 0.35^{\mathrm{a}}$ \\
\hline & Protein $\%$ & $3.74 \pm 0.32^{b}$ & $3.64 \pm 0.13^{b}$ & $5.29 \pm 0.38^{\mathrm{a}}$ \\
\hline & Fat $\%$ & $5.28 \pm 0.94^{b}$ & $5.47 \pm 0.84^{b}$ & $7.58 \pm 1.31^{\mathrm{a}}$ \\
\hline & $\mathrm{pH}$ & $7.64 \pm 0.42^{\mathrm{a}}$ & $7.52 \pm 0.36^{\mathrm{a}}$ & $6.88 \pm 0.21^{b}$ \\
\hline & Density $\mathrm{gm} / \mathrm{ml}$ & $1.029 \pm 0.003^{\mathrm{b}}$ & $1.027 \pm 0.002^{\mathrm{b}}$ & $1.036 \pm 0.003^{\mathrm{a}}$ \\
\hline & Electrical conductivity & $8.36 \pm 0.031^{\mathrm{a}}$ & $6.26 \pm 0.022^{b}$ & $3.8 \pm 0.005^{\mathrm{c}}$ \\
\hline \multirow{7}{*}{$8-9$} & Total solids $\%$ & $12.24 \pm 1.24^{b}$ & $12.53 \pm 1.66^{\mathrm{b}}$ & $16.62 \pm 1.43^{\mathrm{a}}$ \\
\hline & Lactose \% & $3.52 \pm 0.18^{\mathrm{b}}$ & $3.64 \pm 0.32^{b}$ & $4.58 \pm 0.27^{\mathrm{a}}$ \\
\hline & Protein $\%$ & $3.58 \pm 0.21^{\mathrm{b}}$ & $3.66 \pm 0.14^{b}$ & $4.75 \pm 0.26^{\mathrm{a}}$ \\
\hline & Fat $\%$ & $5.11 \pm 0.25^{\mathrm{b}}$ & $5.23 \pm 0.18^{b}$ & $6.68 \pm 0.32^{\mathrm{a}}$ \\
\hline & $\mathrm{pH}$ & $7.64 \pm 0.17^{\mathrm{a}}$ & $7.52 \pm 0.31^{\mathrm{a}}$ & $6.82 \pm 0.11^{b}$ \\
\hline & Density $\mathrm{gm} / \mathrm{ml}$ & $1.026 \pm 0.004^{b}$ & $1.027 \pm 0.002^{b}$ & $1.035 \pm 0.002^{\mathrm{a}}$ \\
\hline & Electrical conductivity & $8.16 \pm 0.31^{\mathrm{a}}$ & $6.26 \pm 0.018^{b}$ & $4.42 \pm 0.007^{\mathrm{c}}$ \\
\hline \multirow{7}{*}{$10-11$} & Total solids \% & $12.91 \pm 1.36^{\mathrm{b}}$ & $13.20 \pm 1.42^{\mathrm{b}}$ & $16.42 \pm 1.37^{\mathrm{a}}$ \\
\hline & Lactose \% & $3.44 \pm 0.21^{\mathrm{b}}$ & $3.56 \pm 0.16^{\mathrm{b}}$ & $4.48 \pm 0.41^{\mathrm{a}}$ \\
\hline & Protein \% & $3.71 \pm 0.18^{b}$ & $3.86 \pm 0.22^{b}$ & $4.66 \pm 0.34^{\mathrm{a}}$ \\
\hline & Fat $\%$ & $5.76 \pm 0.42^{b}$ & $5.78 \pm 0.32^{b}$ & $6.59 \pm 0.42^{\mathrm{a}}$ \\
\hline & $\mathrm{pH}$ & $7.56 \pm 0.22^{\mathrm{a}}$ & $7.38 \pm 0.16^{\mathrm{a}}$ & $6.78 \pm 0.14^{b}$ \\
\hline & Density $\mathrm{gm} / \mathrm{ml}$ & $1.022 \pm 0.006^{\mathrm{b}}$ & $1.025 \pm 0.004^{b}$ & $1.033 \pm 0.003^{\mathrm{a}}$ \\
\hline & Electrical conductivity & $8.21 \pm 0.21^{\mathrm{a}}$ & $6.16 \pm 0.018^{b}$ & $5.42 \pm 0.006^{\mathrm{c}}$ \\
\hline
\end{tabular}

Mean values \pm Standard error (S.E.) significantly different $(\mathrm{P}<0.05)$ between buffaloes, and those of healthy status are labeled with different superscript letters.

Based on the clinical signs and CMT for the milk samples of the buffaloes, the occurrence of mastitis was significantly higher among 10 to 11 -year-old buffaloes at $62.60 \%$ relative risk(RR): 6.796 times, Confidence Interval
(CI): 4.088-11.300] than eight to nine-year-old, six to seven-year-old and four to five-year-old buffaloes, which were $41.22 \%, 24.13 \%$ and $9.21 \%$ respectively (Table 5).The prevalence of mastitis was considerably elevated 
among the third trimester of lactation period $54.93 \%$ (RR: 4.154 times, CI: 2.964- 5.822) compared to the second and first trimesters of lactation period, which were $40.17 \%$ and $13.22 \%$ respectively (Table 5). The occurrence of mastitis was considerably elevated among outdoor feeding animals $49.31 \%$ (RR: 2.028 times, CI:1.652- 2.490) compared to the indoor feeding animals, which were $24.30 \%$ (Table 6). The prevalence of mastitis was considerably higher among large herd sizes (> 30 buffaloes/herd) $44.84 \%$ (RR: 2.273, CI: 1.713-3.015) compared to small herd sizes $(<10$ buffaloes/herd), which were $19.72 \%$. The occurrence of mastitis was considerably elevated among the soil-floored bedding buffaloes $61.72 \%$ (RR: 3.372 times, CI: 2.5244.505) compared to the cement and sand-floored bedding buffaloes which were $25.00 \%, 18.30 \%$ respectively (Table 6). The occurrence of mastitis was considerably elevated in the northern, southern parts of Mosul city, 66.97\%, 48.57\% respectively (RR: 5.357, 3.885 times respectively, CI: 3.253-8.822 and 2.334-6.466 respectively) than the central, eastern and western parts of Mosul city, which were $17.64 \%, 14.51 \%$ and $12.5 \%$ respectively (Table 7 ). The prevalence of the disease was substantially elevated in Spring and Winter seasons, $66.24 \%, 40.75 \%$ respectively
(RR: 6.219, 3.826 times respectively, CI: 3.981-9.715 and 2.401-6.098 respectively) than Autumn and Summer seasons, which were $23.49 \%, 10.65 \%$ respectively (Table $8)$.

The numbers, types and percentages of the bacterial isolates from clinical cases of mastitis were: Staphylococcus aureus, 22 isolates (25.88\%), Streptococcus agalactiae, 16 isolates (18.82\%), Streptococcus pyogenes, 14 isolates (16.47\%), Corynebacterium bovis, 12 isolates (14.11\%), Escherichia coli, 9 isolates (10.58\%), Pseudomonus aeruginosa, 6 isolates (7.05\%) and Pasteurella multocida, 6 isolates $(7.05 \%)$ (Table 9). The numbers, types and percentages of the bacterial isolates from subclinical cases of mastitis were: Staphylococcus chromogens, 32 isolates (14.61\%), Staphylococcus xylosus, 28 isolates (12.78\%), Streptococcus agalactiae, 26 isolates (11.87\%), Streptococcus dysagalactiae, 25 isolates (11.41\%), Streptococcus uberis, 22 isolates (10.04\%), Proteus vulgaris, 22 isolates (10.04\%), Klebsiella pneumonae, 21 isolates (9.58\%), Escherichia coli, 18 isolates (8.21\%), Corynebacterium bovis 16 isolates (7.30\%) and Passteurella multocida, 9 isolates $(4.10 \%)$ (Table 10).

Table 5: Risk of animal factors associated with occurrence of mastitis based on California mastitis test (CMT)

\begin{tabular}{lccccc}
\hline \multirow{2}{*}{ Factors } & \multirow{2}{*}{ Number } & \multicolumn{4}{c}{ California Mastitis test } \\
\cline { 3 - 6 } & & No. of positive (\%) & Relative Risk (RR) & 95\% Confidence Interval (CI) & P-value \\
\hline Age & 152 & $14(9.21)^{\mathrm{a}}$ & 1 & $1.490-4.608$ & 0.0003 \\
\hline 4-5 years & 174 & $42(24.13)^{\mathrm{b}}$ & 2.620 & $2.654-7.548$ & 0.0001 \\
6-7 years & 228 & $94(41.22)^{\mathrm{c}}$ & 4.476 & $4.088-11.300$ & 0.0001 \\
8-9 years & 246 & $154(62.60)^{\mathrm{d}}$ & 6.796 & & \\
10-11 years & & & & \\
\hline Lactation period & 242 & $32(13.22)^{\mathrm{a}}$ & 1 & $2.122-4.348$ & 0.0002 \\
\hline First trimester & 234 & $94(40.17)^{\mathrm{b}}$ & 3.037 & $2.964-5.822$ & 0.0001 \\
Second trimester & 324 & $178(54.93)^{\mathrm{c}}$ & 4.154 & \\
Third trimester & \multicolumn{7}{c}{${ }^{\mathrm{c}}$} &
\end{tabular}

Values significantly different $(\mathrm{P}<0.05)$ between animal factors are labelled with different superscript letters.

Table 6: Risk of the management factors associated with occurrence of mastitis based on California mastitis test (CMT)

\begin{tabular}{lccccc}
\hline \multirow{2}{*}{ Factors } & \multirow{2}{*}{ number } & \multicolumn{4}{c}{ California Mastitis test } \\
\cline { 3 - 6 } & & No. of positive (\%) & Relative Risk & 95\% Confidence Interval & P- value \\
\hline Husbandry & 362 & $88(24.30)^{\mathrm{a}}$ & 1 & & \\
Indoor feeding & 438 & $216(49.31)^{\mathrm{b}}$ & 2.028 & $1.652-2.490$ & 0.0001 \\
Outdoor feeding & & & & \\
\hline Herd size & 218 & $43(19.72)^{\mathrm{a}}$ & 1 & & 0.0001 \\
$<10$ Buffalos & 582 & $261(44.84)^{\mathrm{b}}$ & 2.273 & $1.713-3.015$ & \\
$>30$ Buffaloes & & & & 0.077 \\
\hline Type of floor bedding & 224 & $41(18.30)^{\mathrm{a}}$ & 1 & $0.962-1.937$ & 0.0001 \\
Sand floored & 252 & $63(25.00)^{\mathrm{b}}$ & 1.365 & $2.524-4.505$ & \\
Cement floored & 324 & $200(61.72)^{\mathrm{c}}$ & 3.372 & & \\
Soil floored & &
\end{tabular}

Values significantly different $(\mathrm{P}<0.05)$ between management factors are labelled with different superscript letters. 
Table 7: Risk of the regional factors associated with occurrence of mastitis based on California mastitis test (CMT)

\begin{tabular}{lccccc}
\hline \multirow{2}{*}{ Factors } & $\begin{array}{c}\text { No. of } \\
\text { buffaloes }\end{array}$ & No. of positive $(\%)$ & Relative Risk & 95\% Confidence Interval & P- value \\
\hline Western & 112 & $14(12.5)^{\mathrm{a}}$ & 1 & & \\
Eastern & 124 & $18(14.51)^{\mathrm{a}}$ & 1.161 & $0.606-2.224$ & 0.651 \\
Central & 136 & $24(17.64)^{\mathrm{b}}$ & 1.411 & $0.767-2.597$ & 0.042 \\
Southern & 210 & $102(48.57)^{\mathrm{c}}$ & 3.885 & $2.334-6.466$ & 0.0001 \\
Northern & 218 & $146(66.97)^{\mathrm{d}}$ & 5.357 & $3.253-8.822$ & 0.0001 \\
\hline \multicolumn{7}{l}{ Values significantly different $(\mathrm{P}<0.05)$ between regional factors are labelled with different superscript letters ( $\left.{ }^{\mathrm{a}, \mathrm{b}, \mathrm{c} \text { or } \mathrm{d}}\right)}$.
\end{tabular}

Values significantly different $(\mathrm{P}<0.05)$ between regional factors are labelled with different superscript letters $\left({ }^{\mathrm{a}, \mathrm{b}, \mathrm{c} \text { or } \mathrm{d}}\right)$.

Table 8: Risk of the seasonal factors associated with occurrence of mastitis based on California mastitis test (CMT)

\begin{tabular}{lccccc}
\hline \multirow{2}{*}{ Factors } & $\begin{array}{c}\text { No. of } \\
\text { buffaloes }\end{array}$ & No. of positive $(\%)$ & Relative Risk & 95\% Confidence Interval & P- value \\
\hline Summer & 169 & $18(10.65)^{\mathrm{a}}$ & 1 & & \\
Autumn & 183 & $43(23.49)^{\mathrm{b}}$ & 2.206 & $1.326-3.670$ & 0.001 \\
Winter & 211 & $86(40.75)^{\mathrm{c}}$ & 3.826 & $2.401-6.098$ & 0.0001 \\
Spring & 237 & $157(66.24)^{\mathrm{d}}$ & 6.219 & $3.981-9.715$ & 0.0001 \\
\hline V
\end{tabular}

Values significantly different $(\mathrm{P}<0.05)$ between seasonal factors are labelled with different superscript letters $\left({ }^{\mathrm{a}, \mathrm{b}, \mathrm{c} \text { or } \mathrm{d}}\right)$.

Table 9: Types and frequencies of different bacterial species isolated from clinical Cases of mastitis in buffaloes

\begin{tabular}{llcccccc}
\hline $\begin{array}{l}\text { Type of } \\
\text { animals }\end{array}$ & \multicolumn{1}{c}{ Bacterial species } & $\begin{array}{c}4-5 \\
\text { years }\end{array}$ & $\begin{array}{c}6-7 \\
\text { years }\end{array}$ & $\begin{array}{c}8-9 \\
\text { years }\end{array}$ & $\begin{array}{c}10-11 \\
\text { years }\end{array}$ & $\begin{array}{c}\text { No. of } \\
\text { isolates }\end{array}$ & $\begin{array}{c}\text { Isolation } \\
\text { Percentage (\%) }\end{array}$ \\
\hline \multirow{6}{*}{ Buffaloes } & Staphylococcus aureus & 2 & 4 & 7 & 9 & 22 & 25.88 \\
& Streptococcus agalactiae & 1 & 2 & 6 & 7 & 16 & 18.82 \\
& Streptococcus pyogenes & 2 & 2 & 4 & 6 & 14 & 16.47 \\
& Corynebacterium bovis & 1 & 2 & 4 & 5 & 12 & 14.11 \\
& Escherichia coli & 1 & 1 & 2 & 5 & 9 & 10.58 \\
& Pseudomonus aeruginosa & - & 1 & 2 & 3 & 6 & 7.05 \\
& Pasteurella multocida & 1 & 1 & 2 & 2 & 6 & 7.05 \\
\cline { 2 - 7 } & Total & 8 & 13 & 27 & 37 & 85 & 100.00 \\
\hline
\end{tabular}

Table 10: Types and frequencies of different bacterial species isolated from subclinical cases of Mastitis in buffaloes

\begin{tabular}{llcccccc}
\hline $\begin{array}{c}\text { Type of } \\
\text { animals }\end{array}$ & \multicolumn{1}{c}{ Bacterial species } & $\begin{array}{c}4-5 \\
\text { years }\end{array}$ & $\begin{array}{c}6-7 \\
\text { years }\end{array}$ & $\begin{array}{c}8-9 \\
\text { years }\end{array}$ & $\begin{array}{c}10-11 \\
\text { years }\end{array}$ & $\begin{array}{c}\text { No. of } \\
\text { isolates }\end{array}$ & $\begin{array}{c}\text { Isolation } \\
\text { Percentage }(\%)\end{array}$ \\
\hline \multirow{5}{*}{ Buffaloes } & Staphylococcus chromogens & 1 & 3 & 10 & 18 & 32 & 14.61 \\
& Staphylococcus xylosus & 1 & 3 & 10 & 14 & 28 & 12.78 \\
& Streptococcus agalactiae & 1 & 4 & 7 & 14 & 26 & 11.87 \\
& Streptococcus dysagalactiae & 1 & 4 & 8 & 12 & 25 & 11.41 \\
& Streptococcus uberis & - & 3 & 6 & 13 & 22 & 10.04 \\
& Proteus vulgaris & - & 2 & 6 & 14 & 22 & 10.04 \\
& Klebsiella pneumonae & - & 2 & 7 & 12 & 21 & 9.58 \\
& Escherichia coli & 1 & 3 & 6 & 8 & 18 & 8.21 \\
& Corynebacterium bovis & 1 & 3 & 4 & 8 & 16 & 7.30 \\
& Pasteurella multocida & - & 2 & 3 & 4 & 9 & 4.10 \\
\cline { 2 - 7 } & Total & 6 & 29 & 67 & 117 & 219 & 100.00 \\
\hline
\end{tabular}

\section{Discussion}

In this paper, the total prevalence of the clinical mastitis in buffaloes was $10.62 \%$ based on clinical signs, while the total occurrence of SCM was $27.37 \%$ based on CMT. These outcomes were lower compared with previous outcomes reported by (22) who stated that the occurrences of the clinical and subclinical cases of mastitis in buffaloes in 
Missan City/Iraq were $25.17 \%$ and $31.94 \%$ respectively, according to the clinical signs, bacterial culture and identification techniques. The prevalence of SCM in this study was higher compared to the outcomes reported by (23) who reported the occurrences of SCM in buffaloes were $7.05 \%$ based on CMT.

The statistical analysis of the clinical signs revealed that the infected buffaloes with clinical cases of mastitis had significantly higher heart and respiratory rate/min, rectal temperature, but they had significantly lower values of rumenal movements/5min compared to control and associated with cardinal signs of inflammation such as swelling, heat, redness, discomfort, and edema in the infected quarters with abnormally discolored milk and existence of threads, flakes, and clots in the mastitic milk and this result is compatible with $(1,6,13)$.

A considerable increase was noted in the SCC in the clinical and subclinical instances of the disease in the current study in comparison with the control animals. In the SCM cases the SCC was higher than 200.000 somatic cells/ml of milk, which suggested infection with SCM according to (16-18) who reported that healthy buffalo milk had $<100.000$ somatic cells $/ \mathrm{ml}$ of milk and the buffalo milk having > 200.000 somatic cells $/ \mathrm{ml}$ were considered subclinically infected, while in the clinical cases of mastitis the SCC was higher, ranging between 1.284.000 \pm 36.2 to $1.795 .000 \pm 48.3$ and this result suggested the clinical infection of mastitis according to (23).

The SCC of milk is the true index of intramammary infections. The somatic cells in the milk are of two types, including the blood leukocytes and sloughed epithelial cells of the mammary gland tissues. The epithelial cells are found normally in milk due to the natural breakdown and repair function in the mammary gland tissues, while the leukocytes influx from the blood to the milk, which are drawn by chemical releases from damaged tissues in the mammary gland. The majority of the somatic cells are leukocytes, including neutrophils, lymphocytes and macrophages. The epithelial cells range from $0-7 \%$ of the SCC but the main elevation in SCC occurs because of the flow of neutrophils into the milk (24).

The SCC rises along with the seriousness of the mammary tissue inflammation (6). The SCC is an indicator of the udder inflammation which is used for monitoring udder health and milk quality at quarter, cow, herd and general animal population levels. In the current study the SCC in the milk of old age buffaloes was higher than the SCC of the milk of young age buffaloes and this result suggested the higher occurrence of mastitis in old age buffaloes compared to young age buffaloes due to the higher susceptibility of the old age buffaloes to teat abrasions compared to the young age buffaloes (7).

In the current study there is a substantial decline in lactose levels in the milk samples of the clinical and subclinical forms of mastitis compared to the milk samples of the control group and this result agrees with the that of (24), who reported a considerable decline in the lactose levels in the clinical and subclinical cases of mastitis, which may be attributed to the reduction in the synthetic activities of the mammary gland's epithelial cells.

In the current study, there is a notable decline in the protein content in the milk samples of the clinical and subclinical cases of mastitis in comparison with the milk samples of the control group and this result is compatible with the findings of (25), who revealed a substantial reduction in the protein contents of the mastitic milk, possibly because of the breakdown of milk protein in cases of clinical and SCM, The milk from clinical or subclinical infected animals was found to have an elevated proteolytic enzyme activity (plasmin), and this enzyme caused substantial damage to the milk casein in the mammary gland before the milk was collected from the animal.

This study noted a considerable reduction in the levels of fat in the milk samples of the clinical and subclinical cases of mastitis in comparison with the milk samples of the control, which agrees with the reports of (25) who found significant reduction in the levels of fat in the milk samples of infected animals and this may be attributed to weakened synthesis and the secretion function of the mammary gland's epithelial cells. Furthermore, it may be attributed to the breakdown of fat due to the effects of lipase enzyme, which attacks the triglycerides in the milk and releases free fatty acids that may produce a rancid offflavor from the mastitic milk (23).

This current study also witnessed a noticeable rise in the $\mathrm{pH}$ values in the milk samples of the clinical and subclinical forms of mastitis in comparison with the milk samples of the control. This result is in agreement with the results reported by (24), that the $\mathrm{pH}$ values increase significantly in mastitic milk samples in comparison with normal milk samples, probably because of the increased permeability of the udder tissue to blood components leading to their higher values in the milk, such as increased influxes of bicarbonate ions from the blood stream into the milk. The movement of alkaline salts from the blood to the milk makes the milk more alkaline, showing $\mathrm{pH}$ values over 7 and this result is compatible with (26). Besides, (27) mentioned that the elevated SCC in the mastitic milk led to elevation in the $\mathrm{pH}$ values of the milk, which may be due to increase in alkaline salt production in the udder of the infected animals with mastitis.

The current study witnessed a considerable increase in the EC of the milk samples of clinically and subclinicallyinfected animals in comparison with the control animals. This result was concurring with the findings of (28) who reported that the range of the EC of healthy milk was 3.05.48 (melli Seimens) $\mathrm{mS} / \mathrm{cm}$ and the range of $\mathrm{EC}$ of the subclinical mastitis ( $\mathrm{SCM}$ ) was $5.50-6.50 \mathrm{mS} / \mathrm{cm}$, while the range of EC of the clinical mastitis was $6.5-8.5 \mathrm{mS} / \mathrm{cm}$. Furthermore, (24) revealed considerable increases in the EC 
of milk samples of mastitis-infected animals. The rise in the EC may be attributed to the increased levels of $\mathrm{Na}^{+}$and $\mathrm{Cl}^{-}$ ions and reductions in the concentrations of lactose and $\mathrm{K}^{+}$ions. There are two factors that cause these alterations in the ionic levels in mastitic milk namely the damage of the active ion pumping system, and increased permeability of the blood capillaries. These changes in the levels of $\mathrm{Na}^{+} \mathrm{Cl}^{-}$ and $\mathrm{K}^{+}$ions in the milk during mastitis lead to higher $\mathrm{EC}$ of the milk. The EC of the milk has a positive correlation with the SCC, so the detection of mastitis can be confirmed by the measurement of the EC of the milk.

Moreover, considerably higher occurrence of mastitis was noted in this study among old age buffaloes of 10-11 years and 8-9 years in comparison with medium age buffaloes of 6-7 years, and young age buffaloes of 4-5 years, and this result is compatible with $(7,24)$ who states that the maximum occurrence of mastitis occurs in buffaloes aged 11 years and older $72.72 \%$, while the lowest occurrence of mastitis in buffaloes occurs in buffaloes aged $5-6$ years $3.46-4.25 \%$.

The existence of mastitis was found in this study to be significantly elevated in the third trimester of lactation period, and this result mirrors that of (24), who reported increased occurrence of mastitis in the third trimester compared to the first and second trimesters of lactation period, and this may be attributed to decreased host immune defense capabilities during the third trimester of lactation period in buffaloes, in addition to more susceptibilities of the udder in the third trimester of lactation to environmental and contagious pathogens. Furthermore, (29) reported the maximum occurrence $71.43 \%$ of SCM at the third trimester of lactation period in comparison with mid and first trimesters.

The prevalence of mastitis in the current study in outdoor feeding animals was higher compared to the indoor feeding buffaloes, and this may be attributed to higher susceptibility of the outdoor feeding animals to abrasions and injuries of the teats and the udder tissues during grazing compared to the indoor feeding animals and this result is compatible with (27). Besides, the susceptibility of the outdoor feeding animals to the environmental and contagious pathogens is higher than the indoor - feeding animals.

In this present study, the occurrence of mastitis was more predominant in the large size herds (> 30 buffaloes) than the small size herds ( $<10$ buffaloes), and this may be attributed to the overcrowding of the animals in the herd and increased transmission of contagious pathogens from the infected animals to the healthy animals which reflects incorrect farm management, general discomfort and mammary stress leading to the production of poor milk quality (6).

The occurrence of mastitis in the present work was determined to be considerably higher in animals reared in soil-floored farms, whereas lower occurrence was reported in buffaloes reared in cement and sand floored farms, and this result is compatible with (2) who reported highest occurrence of mastitis in animals reared on soil-floored farms, and lower occurrence in animals reared on cement and sand floored farms with $29 \%$ and $27 \%$ respectively, and this may be attributed to the fact that the soil floored farms provide favorable conditions for bacterial growth more than the cement and sand floored farms. This is because in the soil floored farms, the teats of the animals are exposed to the pathogenic bacteria, leading to increased probabilities of mastitis in buffaloes.

The occurrence of mastitis in the present research was determined to be higher in the northern and southern parts of the Mosul city/Iraq, than the central, eastern and western parts of the city, and this may be attributed to the intensively managed buffaloes and high stocking density, in addition to dirty bedding, poor ventilation, and infected utensils in the northern and southern parts of the city, and this result is compatible with (29) who also reported highest occurrence of mastitis in high intensively managed animals.

The occurrence of mastitis in this present study was considerable higher in Spring and Winter seasons than in Autumn and Summer seasons, and this result agrees with $(30,31)$ who revealed highest prevalence of mastitis during Spring and Winter seasons, which may be due to high rainfall and high humidity in Spring and Winter seasons in Mosul city/Iraq, during which the chances of contamination of the teats and udders with mud and infected manures are higher than during other seasons and provides a favorable conditions for substantial bacterial growth.

This present study found that the highest occurrence of bacterial infections in the clinical cases of mastitis was Staphylococcus aureus followed by Streptococcus agalactiae and Streptococcus pyogenes. The current study also found that the predominant bacteria in clinical cases of mastitis were Staphylococcus aureus and this result is compatible with $(32,33)$ who noted that the Staphylococcus aureus were the predominant bacteria $38 \%, 54.55 \%$ respectively. Besides, (34) reported higher occurrence of Staphylococcus aureus in clinical cases of mastitis, which was $48.57 \%$, while $(35,36)$ reported that the coagulase negative Staphylococci (CNS) were the most predominant bacterial species in clinical cases of mastitis in buffaloes.

In the case of the current study, the highest occurrence of bacterial species in the subclinical cases of mastitis was Staphylococcus chromogens 32 (14.61\%), followed by Staphylococcus xylosus 28 (12.78\%), Streptococcus agalactiae 26 (11.87\%) and Streptococcus dysagalactiae 25 (11.41\%). In the subclinical (SC) cases of mastitis, the predominant bacteria were Staphylococcus chromogenes 32 $(14.61 \%)$ and this finding was compatible with (37) who mentioned that the commonest isolates from the milk of buffaloes were Staphylococcus chromogenes, Staphylococcus hyicus and Streptococcus uberis, while (2) reported that the prevalence of Streptococcus agalactiae 
and Streptococcus dysagalactiae from subclinical cases of mastitis in buffaloes were $3.12 \%$, and $0.62 \%$ respectively. Furthermore, (36) mentioned that the occurrence of Streptococcus agalactiae was $4.4 \%$, Streptococcus dysagalactiae, 5.6\%, while (37) mentioned that the prevalence of Streptococcus uberis was $4.28 \%$, and Streptococcus dysagalactiae was $11.42 \%$ in the SC cases of mastitis.

\section{Conclusion}

Mastitis leads to a significant reduction in the levels of total solids, lactose, protein, fat, density, and a significant rise in the levels of $\mathrm{pH}$ values and electrical conductivity of the milk samples of clinical and subclinical cases of mastitis. The occurrence of SCM was higher compared to the clinical cases in buffaloes, and the occurrence of mastitis in old age buffaloes was higher than the young age buffaloes.

\section{Acknowledgement}

The authors wish to like to thank the College of Agriculture and Forestry, University of Mosul for financially supporting the surveillance work.

\section{Conflict of interest}

The authors declare no conflicts of interest.

\section{References}

1. Constable PD, Hinchcliff KW, Done SH, Grunberg W. Veterinary medicine a textbook of the diseases of cattle, horses, sheep, pigs, and goats. $11^{\text {th }}$ ed. New York: Elsevier press; 2017. $1904-1914$ p.

2. Baloch H, Rind R, Rind MR, Kumar V, Baloch N, Oad RK. Effect of diverse factors on the frequency of clinical and subclinical mastitis in Kundhi buffaloes of Sindh, Pakistan. Pak J Zool. 2018;50(5):16191628. DOI: $10.17582 /$ journal.pjz/2018.50.5.1619.1628

3. Du Preez JH, Giesecke WH. Mastitis. In: Coetzer JA, Thomson GR. Infectious diseases of livestock. Oxford: Oxford University Press; 1994. $1564-1595 \mathrm{p}$.

4. Sharma A, and Sindhu N. Occurrence of clinical and subclinical mastitis in buffaloes in the State of Haryana (India). Italian J Anim Sci. 2007;6(2):965-967. DOI: 10.4081/ijas.2007.s2.965

5. Naiknaware HS, Shelke DD, Bhalerao DP, Keskar DV, Jagadesh S, Sharma LK. Prevalence of subclinical mastitis in buffaloes in and around Mumbai. Indian Vet J. 1998;75:291-292. DOI: $\frac{10.3923 / \text { pibs.2013.1776.1780 }}{\text { A }}$

6. Fagiolo A, Lai O. Mastitis in buffalo. Italian J Anim Sci. 2007;6(2):200-206. DOI: 10.4081/ijas.2007.s2.200

7. Kavitha KL, Rajesh K, Suresh K, Satheesh K, Sundar NS. Buffalo mastitis - risk factors. Bull. 2009;28:135-137. [available at]

8. Zubairi RB. Genetic detection to Aeromonas hydrophila proteolytic activity in milk samples (cows, buffaloes and goats) in Basra governorate. Iraqi $\mathbf{J}$ Vet Sci. 2020,34(2):253-258. DOI: 10.33899/ijvs.2019.125888.1174

9. Mohammed ZA. Association between clinical and subclinical mastitis and reproductive performance of cows at Nottingham dairy center. Iraqi J Vet Sci. 2021;35(2):343- 350. Doi: 10.33899/ijvs.2020.126843.1398
10. Ahmed IM. Detection of CTX-M gene in extended spectrum Blactamases producing Enterobacteriaceae isolated from bovine milk. Iraqi J Vet Sci. 2021;35(2):397- 402. Doi: 10.33899/ijvs.2020.126909.1412

11. Banaei RA, Mahdavi S. Detection of the hbl complex genes in Baccilus cereus isolated from cow raw milk in northwest of Iran. Iraqi J Vet Sci. 2020;34(2):459- 463. DOI: 10.33899/ijvs.2020. 126120.1238

12. Al-Zainy ZOA, Al-Jeburii KOS. Prevalence of gram positive bacteria in buffalo mastitis in Iraq. Inter J Adv Res. 2015;3(4):216-225. [available at]

13. Purohit GN, Gaur M, Shekher C. Mammary gland pathologies in the parturient buffalo. Asian Pacific J Reprod. 2014;3(4):322-336. DOI: 10.1016/S2305-0500(14)60048-8

14. Ceron-Munoz M, Tonhati H, Duarte J, Oliveira J, Munoz-Berrocal M, Jurado-Gomez H. Factors affecting somatic cell counts and their relations with milk and milk constituent yield in buffaloes. J Dairy Sci. 2002;85:2885-2889. DOI: $10.3168 /$ jds.S0022-0302(02)74376-2

15. Dhakal IP. Normal somatic cell count and subclinical mastitis in Murrah Buffaloes. J Vet Med. 2006;53:81-86. DOI: 10.1111/j.14390450.2006.00918.x

16. Mahendra S, Dang R. Range of somatic cell count of milk. India: National Dairy Research Institute; 2001.

17. Smith KI. A discussion of normal and abnormal milk based on somatic cell counts and clinical mastitis. Bulletin FIL-IDF. 2002; 372:43-45. [available at]

18. Pyorala S. Indicators of inflammation in the diagnosis of mastitis. Vet Res. 2003;34:565-578. DOI: 10.1051/vetres:2003026

19. Piccinini R, Miarelli M, Ferri B, Tripaldi C, Belotti M, Dapra V, Orlandini S, Zecconi A. Relatioship between celluler and whey components in buffalo milk. J Dairy Res. 2006;73:129-133. DOI: $10.1017 / \mathrm{S} 0022029905001548$

20. Coles EH. Veterinary clinical pathology. $4^{\text {th }}$ edition. London: Saunders Co.; 1986. 359-367 p.

21. Quinn PJ, Carter ME, Markey BK, Carter GR. Clinical veterinary microbiology. London: Mosby; 2004. 215-276 p.

22. Yass AA, Kalra DS, Khalaf AM. Studies on mastitis in buffaloes in Iraq: Prevalence rate and etiology. Trop Vet Anim Sci Res. 1983;1(1):23-28. [available at]

23. Miller RH, Paape MJ. Effects of parity, bacteriological status, stage of lactation, and dry period on N-acetyl-B-D-glucosaminidase activity of milk and dry secretions. J Dairy Sci. 1985;71:2508-2512. DOI: 10.3168/JDS.S0022-0302(88)79838-0

24. Rawdat AM, Omaima NM. Some biochemical changes in serum and milk of mastitic buffaloes. Egyp J Agri Res. 2000;78(4):1737-1747. [available at]

25. Uallah T, Ahmad MQ, Bilal ZR, Muhammad G, Rahman SU. The effect of severity of mastitis on protein and fat contents of buffalo milk. Pakistan Vet J. 2005;25(1):1-4. [available at]

26. Bhoyar AR. Effect of subclinical mastitis on composition of crossbred cow [master's thesis]. India: University of Delhi, College of Veterinary Medicine; 2006. 6-111 p.

27. Moroni P, Rossi CS, Pisoni G, Bronzo V, Castiglioni B, Boettcher PJ. Relationships between somatic cell count and intramammary infection in buffaloes. J Dairy Sci. 2006;89:998-1003. DOI: 10.3168/jds.S00220302(06)72165-8

28. Fahmid S, Hassan F, Naeem H, Barrech S, Lodhi S, Latif S. Determination of mastitis by measuring milk electrical conductivity. Inter J Advan Res Biol Sci. 2016;10:1-4. DOI: 10.22192/ijarbs.2016.03.10.001

29. Rabbani AFM, Samad MA. Host determinants based comparative prevalence of subclinical mastitis in lactating Holstein Frisian cross cows and Red Chittagong cows in Bangladesh. Bangladesh J Vet Med. 2010;(8):17-21. DOI: 10.3329/bjvm.v8i1.7397

30. Ranjan R, Gupta MK, Singh KK. Study of bovine mastitis in different climatic conditions in Jharkhand. Indian Vet World. 2011;(4):205208. DOI: $10.5455 /$ vetworld.2011.205-208

31. Sentitula B, Yadav R, Kumar R. Incidence of Staphylococci and Streptococci during winter in mastitis milk of Sahiwal cow and 
Murrah buffaloes. Indian J Microbiol. 2012;52:153-159. DOI: 10.1007/s12088-011-0207-1

32. Memon MI, Mirbahar KB, Memon MR, Akhtar N, Soomoro SA, Dewani. A study on the etiology of subclinical mastitis in buffaloes. Pakistan J Agri Engg Vet Sci. 1999;15:34-36. [available at]

33. Bhalerao DP, Jagadish S, Keskar DV, Dangore AD, Sharma LK. Antibiogram and treatment of bovine subclinical mastitis. Indian Vet J. 2000;77:244-246. [available at]

34. Baloch H, Rind R, Kalhoro DH, Kalhoro AB. Study on the incidence of clinical mastitis in buffaloes caused by bacterial species. Pakistan J Agri Engg Vet Sci. 2011;27(1):83- 93. [available at]

35. Vajdi HR, Farhoudi MM, Mohammad SM. Mirzaii, H. Bacterial pathogens of intramammary infections in Azeri buffaloes of Iran and their antibiogram. African J Agri Res. 2011;6(11):2516-2521. DOI: 10.5897/AJAR10.204

36. Dhakal IP, Dhakal P, Koshihara T, Nagahata H. Epidemiological and bacteriological survey of buffalo mastitis in Nepal. J Vet Med Sci. 2007;69:1241-1249. DOI: $10.1292 /$ jvms. 69.1241

37. Trinidad P, Nickerson SC, Alley TK, Adkinson RW. Prevalence of intra mammary infection and teat canal colonization in unbred and primigravid heifers. J Dairy Sci. 1990;73:107-114. DOI: 10.3168/jds.S0022-0302(90)78652-3

\section{التهاب الضرع السريري وتحت السريري في الجاموس في منطقة الموصل، العرئرئ}

عبدالستار سالم سعدون

قسم الإنتاج الحيواني، كلية الزراعة والغابات، جامعة الموصل، الفرل الموصل، العراق التناج العرات

الخلاصة

تستهدف هذه الدراسة التحري عن نسبة حدوث التهاب الضرع

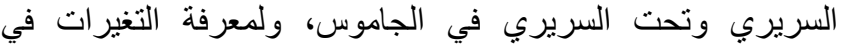
مكونات الحليب، وللتحري عن عددي من عن عوامل الخطورة الوبائية

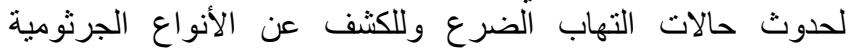

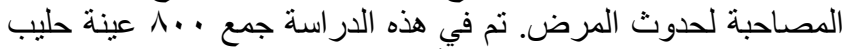

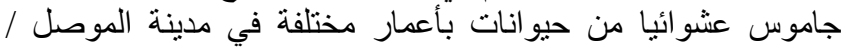
العراق وتم فحصها باستخدام اختبار كاليفورنيا وجهاز تحليل ماتيل الحليب

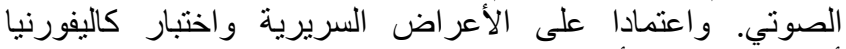

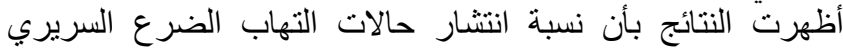

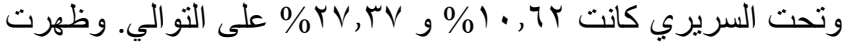
زيادة كبيرة في أعداد الخلايا الجسمية / مل من الحليب في في كلات حالتي

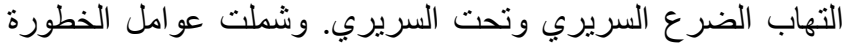

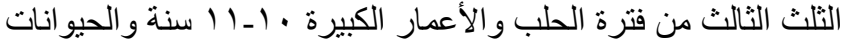

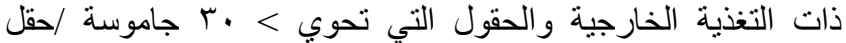

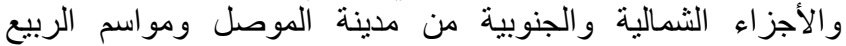

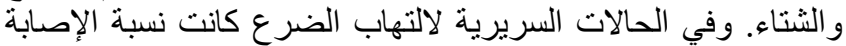

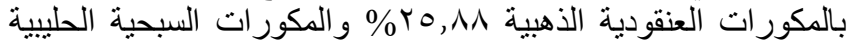

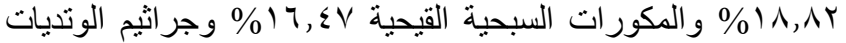

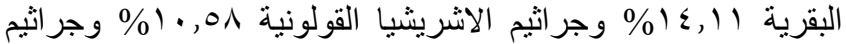

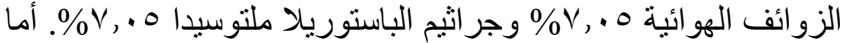

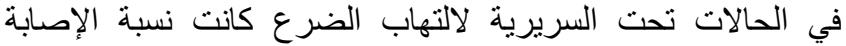

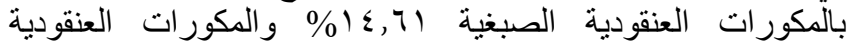

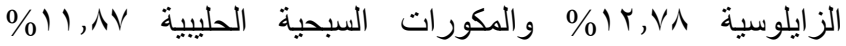

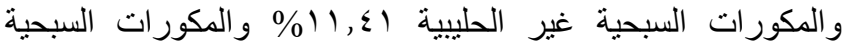

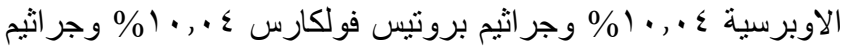

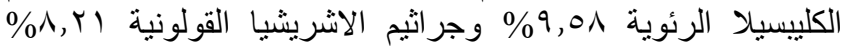

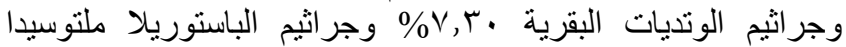

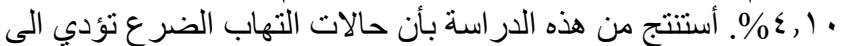

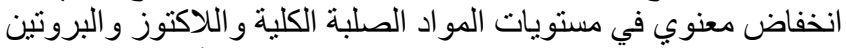
و الدهن وكثافة الحليب وارتفاع معنوي في مستوى الأس الهيدروجيني

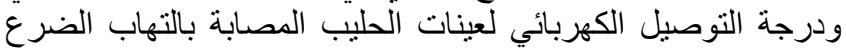
السريري وتحت السريري. 